\title{
To Examine the Drought Pattern during Pre and Post Global Warming Behind and it Impacts on Rice Productivity for Different Districts of Chhattisgarh, India
}

\author{
Yogesh Mahesh ${ }^{1}$, A.S.R.A.S. Sastri ${ }^{1}$, S.K. Chandrawanshi ${ }^{2 *}$, Pandurang Bobade ${ }^{1}$, \\ Hemant Kumar Bhuarya ${ }^{1}$, Deepak K. Kaushik ${ }^{1}$ and Pritpal Singh ${ }^{1}$ \\ ${ }^{1}$ Department of Agrometeorology, Collage of Agriculture, Indira Gandhi Krashi \\ Vishwavidhyalaya Raipur-4912 012, India \\ ${ }^{2}$ Agricultural Meteorological Cell, Department of Agricultural Engineering Navsari \\ Agriculture University, Navsari-396 450, Gujarat, India \\ *Corresponding author
}

\begin{abstract}
A B S T R A C T
\end{abstract}
The study the drought pattern during pre and post global warming behind for different districts of Chhattisgarh the drought pattern in the back drop of climate change due to

Keywords

Pre and Post Global warming, Climate change, Agriculture and drought

\section{Article Info}

Accepted: 04 October 2018 Available Online: 10 November 2018 global warming was examined. It is very clear from the analysis that the number drought years in a 40 years period had drastically increased during post global warming period (1971-2010) as compared to pre global warming period. This a clear evidence of the impact of regional climate changes due to global warming on the rainfall pattern in all the districts of Chhattisgarh state. Studies are also made to assess the impacts of drought at seedling, vegetative, reproductive and at all stages on the productivity of rice in 4 districts viz. Raipur, Bilaspur, Jagdalpur and Ambikapur districts. From this analysis it was found that due to seedling stage drought the yield loss of rice in different districts varied from 6.3 to 22.7 percent. In case of reproductive stage drought the yield loss varied from 20.2 to 41.1 percent in different districts. When drought at all stage was examined the yield loss varied from 34.1 to 57.4 percent. Thus, in Chhattisgarh state drought incidence has become a regular phenomenon during post-global warming period and there is a considerable and significant impact on rice productivity. Thus, the rice cultivation in Chhattisgarh had become risky under rainfed conditions and therefore the government is recommending crop diversification in these unproductive areas.

\section{Introduction}

In Chhattisgarh state rice is the predominant crop grown under rainfed conditions. Farmers broadcast the seeds immediately after the onset of monsoon in a pre-ploughed field. They usually take long duration (more than
140 days) varieties, which flower in midOctober and mature by mid - November while South-west monsoon withdraws by midSeptember. Hence terminal drought is a recurring feature for rice crop in this area. Also due to intermittent dry spells water stress conditions occur at different growth stages 
during crop growth period. In view of this, analysis of drought at different growth stages and its impact on rice productivity was carried out for four districts viz. Raipur, Bilaspur, Jagdalpur and Ambikapur districts. Subramaniam and Srimannarayana (1991) carried out rainfall variability studies in Madhya Pradesh. It was found that the coefficient of variation of annual rainfall was less than $20 \%$ for the eastern and southwestern district of east Madhya Pradesh and that of in west Madhya Pradesh the coefficient of variation of annual rainfall ranged from 25 percent over Seoni district in the east to nearly 40 percent in Murena district in the extreme north west. Further, they concluded that the coefficient of variation of rainfall was very high in winter, hot weather and post-monsoon seasons over the state. Baghel and Sastri (1992) studied the impact of regional climatic change and its influence on agriculture in Chhattisgarh region Madhya Pradesh. They found that the quantum of annual rainfall was in decreasing trend in some pockets. Subramaniam (1994) used the rainfall data of 90 years period from 1901-1990 to examine the possibilities of various meteorological subdivisions to recover its June-July deficiency during the later half of the south- west monsoon period. He found that east Madhya Pradesh recovers its June- July rainfall deficiency in September with a relatively high percentage $(21 \%)$ whereas, in the west Madhya Pradesh the deficiency worsens further in September (-7\%). Suresh (1996) analysed the inter-seasonal and inter-annual rainfall of 9 meteorological sub divisions in Tamilnadu, Kerala, Andhra Pradesh and Karnataka states for the period of 1901-1992. The large scale excess and deficit rainfall years were identified for all the sub-divisions. The increasing and decreasing trend of rainfall activities were statistically examined and periodicities of the rainfall, time series was worked out by employing spectrum analysis. So for as the statistical parameters and properties of various meteorological subdivisions is concern, he observed that there was a significant decreasing trend in southwest, north-east monsoon and annual rainfall in respect of Kerala from 1976. The performance of south- west monsoon and thereby annual rainfall activity was on the increasing trend in Telangana, north interior Karnataka from 1953. Jadhav et al., (1999) analyzed the rainfall probability for crop planning in scarcity zone of Maharashtra. The rainfall data of 30 years (1966-1995) was analyzed for rainfall probability at various probability levels (30, 60, 70 and $90 \%)$ and weekly, monthly, seasonal and annual trends were worked out at Solapur. They found that on an average annual rainfall of Solapur region was $723.4 \mathrm{~mm}$ received in 43 rainy days. The mean monthly rainfall of Solapur was $113.3,127.7,140.3$ and $172.3 \mathrm{rnm}$ in the months of June, July, August and. September month, respectively with the total monsoon rainfall of $553.8 \mathrm{~mm}$. The seasonal rainfall for these months accounted for 76 per cent of the annual rain fall. Sastri et al., (2002) Carried drought analysis and its impact on rice productivity in Chhattisgarh for the period of 1997-2002. They concluded that in the years 2000 and 2002 there was early season drought because of this beushening operation could not be done. Das et al., (2002) evaluated agricultural drought for dryland crops, using the weather data of 40 years i.e., from 19511990. Based on the 40 years data, normal weekly rainfall and its variability. Water balance was computed by using Thornthwaite water balance equation and evapotranspiration by Penman's modified method. They concluded that when the drought condition occurred during different phenological stages of the crop, the method used (moisture deficit index) assist farmers to make critical management decisions. Sarkar (2000) studied agricultural drought of 1987 monsoon season in India by using Thornthwaite's weekly water balance technique. The results revealed that a 
major portion of the Gujarat state had continuously been under the grip of moderate to severe drought conditions since 18-24 June till September end. Other areas substantially affected were Rajasthan, Punjab. Haryana, coastal Andhra Pradesh, Madhya Pradesh, Uttar Pradesh and Vidarbha where prolonged drought spell abating only for short periods in the season. Subrarnaniam and Srimannarayana (1991) carried water balance studies of 21 stations in Madhya Pradesh on the basis of Thornthwaite's book keeping procedure for the period of 30 years. The distribution of water deficiency showed a major portion of the state had more than $500 \mathrm{~mm}$ of annual water deficiencies with a small portion in the east, registering less than $500 \mathrm{~mm}$. It was also evident that western part of the state experienced the maximum amount (greater than $600 \mathrm{~mm}$ ) of water deficiency. Further, they found that the mean annual water surplus was more than $400 \mathrm{~mm}$ in the eastern side and less than $100 \mathrm{~mm}$ in the western and northern portions. Rawat and Rawat (1995) studied changes in hydrology and water balance of new forest Dehradun by using the water balance method of Thornthwaite and Mather (1955) for the period of 1931-1990. It was observed that the annual averages of rainfall and surplus values had decreased from the first three decades (1931-1960) to the later three decades (1961-1990). Further, they concluded that surplus value was the lowest during the last decade as compared to earlier decades. Sastri et al., (1997) carried hydroclimatic analysis for computing water harvesting potential in Chhattisgarh plains by using water balance technique. They found that the water harvesting potential was high in Dharsiwa, Simga and Arang blocks of Raipur as compared to other areas. Paul et al., (2001) carried water balance studies of Bhubaneshwar for the last 4 decades 1961-70, 1971-80, 1981-90, and 1991-96 using the climatic water balance method of Thornthwaite. They noticed that an increase in potential evapotranspiration and actual evapotranspiration and decrease in water surplus from 1961-70 to 1991-96. Srivastava et al., (2000) studied the drought and rice productivity in Chhattisgarh state especially for Raipur, Durg and Rajnandgaon districts. Drought frequency based on aridity index for few stations of Raipur districts and for different decades was worked out and found that mild to moderate droughts were more frequent in the region. For obtaining a clear impact of drought intensity on rice productivity, trends of rice productivity during normal as well as severe drought years at Raipur were worked out. It was concluded that productivity under both the situations showed increasing trend over the study period which was mainly attributed to improved technology.

Also in recent years climate change is a burning issue all over the world. The global warming period was considered from 1970 onwards. Hence the drought pattern during pre (1931-1970) and post (1971-2010) global warming periods was also studied.

\section{Materials and Methods}

\section{Description of the study area}

Chhattisgarh state is a newly created state which came in to existence on $1^{\text {st }}$ November, 2000, as result of bifurcation of the state of Madhya Pradesh. Chhattisgarh state, situated in Eastern India, is located between $17^{\circ} 41^{\prime} \mathrm{N}$ and $24^{\circ} 45^{\prime} \mathrm{N}$ latitudes and $79^{\circ} 30^{\prime} \mathrm{E}$ and $84^{\circ}$ $15^{\prime} \mathrm{E}$ longitudes. It is surrounded in the west by Madhya Pradesh and Maharashtra, in the north by Madhya Pradesh, in the east by Orissa and Jharkhand (the new state separated from Bihar) and in the south by Andhra Pradesh.

The state has 27 districts viz. Raipur, Mahasamund, Rajnandgaon, Durg, Dhamtari, Kawardha, Bilaspur, Janjgir, Korba, Jashpur, 
Raigarh, Ambikapur, Koria, Kanker, Jagdalpur, Dantewada, Narayanpur, Bijapur, Mungeli, Gariyabandh, Balod, Balauodabajar, Bemetara, Surajpur, Sukma, Kondagaon and Balrampur spreading over a geographical area of 137.90 lakh hectares. However, long term meteorological data are available for 16 districts only as other districts are formed recently. Hence, only 16 districts were taken for the study and the geographical locations are as shown in the following Table 1.

\section{Data base}

\section{Rainfall data}

District wise annual rainfall data for the period 1901-2010 and weekly rainfall data for the period of 2001-2010 for Chhattisgarh state were obtained from the Department of Agricultural Meteorology, IGKV, Raipur. Shows Table 3.

\section{Rainfall analysis}

\section{Data availability}

Analysis for rainfall at different districts, the annually rainfall data of 16 districts having long term records have been considered. The data base thus considered is as follows.

However, the data base for all the 16 districts is not the same. In some districts it is available from 1901 onwards and for other districts it is available from later years. The data base for different districts shown in Table 3.

\section{Rainfall departure (\%)}

The percentage rainfall departures from the normal values have been worked as follows

Departure $\%=\frac{\mathrm{X}-{ }^{\overline{\mathrm{X}}}}{\overline{\mathrm{X}}}$
Where,

$\mathrm{X}=$ Rainfall in a given year

$\overline{\mathrm{X}}=$ Mean of the data base

\section{Meteorological drought}

Using the rainfall departures, the different categories of drought have been categorised for different years in different districts using the following criterion-

\section{Productivity of rice}

Data of rice productivity for the Kharif season for Chhattisgarh state were collected from the Department of Agro-meteorology, IGKV, Raipur for the period of 2001-2002 to 201011of Raipur, Bilaspur, Ambikapur and Jagdalpur districts.

\section{Drought impact on rice crops}

An index of moisture adequacy (Ima) has been calculated by computing the weekly water balance. The Ima is the ratio of AET to PET, expressed as percentage

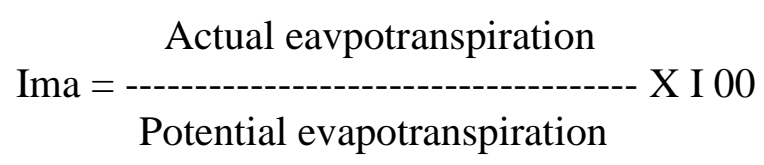

The value of Ima $=100$ indicates that the AET is equal to PET and that there is no moisture stress to the crop. For rice crop, potential evapotranspiration is needed during vegetative and reproductive stages and during seedling and maturity stages values of Ima can be less than $100 \%$.

Using the above concept, the Ima requirement for rainfed rice crop as considered by Sastri, (2006) is as follows

Keeping the above condition in view, the minimum required values of Ima at different 
phenological stages for rice crops were used. The moisture stress condition at different stages was analyzed by superimposing the minimum required values of Ima at different stages.

\section{Potential evapotranspiration}

The weekly potential evapotranspiration for 4 districts for the period 2001-2010 was computed using the following formula of Penman's modified equation.

$\mathrm{E}_{0}=\frac{\Delta \mathrm{Q}_{\mathrm{n}}+{ }_{\gamma} \mathrm{E}_{\mathrm{a}}}{\Delta+{ }_{\gamma}}$

Where,

$\mathrm{Q}_{\mathrm{n}}=$ Net radiation in $\mathrm{mm}$ of water

$\mathrm{Q}_{\mathrm{n}}=\mathrm{Q}_{\mathrm{A}}(1-\mathrm{r})(0.18+0.55 \mathrm{n} / \mathrm{N})-\sigma \mathrm{Ta} 4(0.55-$

$0.092 \sqrt{ }$ ed $)(0.10+0.90 \mathrm{n} / \mathrm{N})+\quad 0.35($ ea-ed $)$

$\left(1+\mathrm{U}_{2} / 100\right)$

Where,

$\mathrm{Q}=$ Extra- terrestrial radiation

$\mathrm{R}=$ albedo

$\mathrm{n}=$ actual sunshine hour

$\mathrm{N}=$ possible sunshine hour

$\sigma=$ Stephan Boltzmann constant

$\mathrm{Ta}=$ air temperature $\left({ }^{\circ} \mathrm{c}\right)$

ea $=$ saturated vapour pressure

ed $=$ actual vapor pressure

$\mathrm{U}_{2}=$ wind speed at 2 meter height

\section{Results and Discussion}

\section{Drought patterns during pre and post global warming period}

By analyzing the rainfall data it was found that the rainfall is decreasing in almost all districts. In order to examine the effect of global warming on the regional rainfall pattern and subsequently on drought pattern, the drought intensities during pre and post global warming periods were analyzed for different districts and are shown in Table 4. When the total numbers of drought years for each district were examined it is found that the total numbers of drought years increased, significantly in all the districts. For example in Mahasamund district during the pre-global warming period (1931-1970) were 4 on 4 only while in the post global warming period (1971-2010) there were 24 years. Similarly in Raigarh district during the pre-global warming period there is only one drought in 40 years while in post global warming period there were 22 droughts. In this analysis the mild drought is not considered because mild drought may not reduce rice drastically.

In Dhamtari there were 5 years of drought during the pre-global warming period there were 21 years of drought during post global warming period. In Rajnandgaon which is in the rain shadow area the numbers of drought years was high in both pre and post global period. The numbers of drought year's increase from 8 to 16 . In other districts the numbers of drought years varied from 1 to 8 years in the 40 years pre global warming period while in post global warming period of 40 years the numbers of drought years ranged from 6 to 24 in different districts. Thus, it is the clear cut evidence that due to global warming there is a significant impact on the rainfall pattern in Chhattisgarh and as a result the drought situation has increased in all the districts of Chhattisgarh. This is one of the causes of the low productivity of rice in Chhattisgarh state.

The total drought pattern during pre and post global warming periods in different districts of Chhattisgarh are shown in Figure 1. It can clear be seen that in Mahasamund, Dhamtari and Raigarh districts suffered from frequent drought during the post global warming 
period. Bastar district had least numbers of drought years even during the post global warming period. The other districts which suffered from drought in the post global warming period are Rajnandgaon, Durg and Surguja followed by Raipur, Koriya and Kawardha. Thus, the rice cultivation in Chhattisgarh had become risky under rainfed conditions and therefore the government is recommending crop diversification in these unproductive areas.

\section{Impact of drought at different growth stages of rice crop}

For assessing the impact of drought/water stress on rice crop at different growth stages, the values of Ima, which the percentage ratio of $\mathrm{AE} / \mathrm{PE}$ is considered. For this purpose climatic water balance for the period was computed for 4 districts of Chhattisgarh, Thornthwaite and Mather (1955). The outcome of the water balance computations.

For assessing the impact of water stress, the average Ima requirement at different crop growth stages of rice crop were assumed at follows
Seedling stage $-75 \%$

Vegetative stage $-100 \%$

Reproductive stage $-100 \%$

Maturity stage $-50 \%$

For analyzing the impact of drought at different growth stages, the crop sowing period which varies from year to year need to be assessed.

\section{Crop sowing period}

The crop sowing period was worked out with the concept of sowing rains.

The sowing rains for each and each districts were considered as "one or two consecutive weeks where there is rainfall of more than 50 $\mathrm{mm}$ ".

Using this criterion the sowing period for each year and each district was found out and the results are shown in Table 2. It can be seen that in Raipur district the sowing rain period during the period of 10 year varied from 24 to 27 standard meteorological weeks (SMW) while at Ambikapur it varied from 24-29 SMW.

\section{Meteorological drought}

\begin{tabular}{|c|c|}
\hline Rainfall departure & Drought severity \\
\hline 0 to -19.9 & Mild* \\
\hline-20 to -39.9 & Large \\
\hline-40 to -59.9 & Severe \\
\hline$\leq 60.0$ & Disastrous \\
\hline
\end{tabular}

(* for rain fed rice crop even a departure from normal values creates water stress conditions and hence it is categorized as mild drought)

\section{Drought impact on rice crops}

\begin{tabular}{|l|c|}
\hline \multicolumn{1}{|c|}{ Crop stage } & Minimum Ima (\%) \\
\hline Seedling stage & 75 \\
\hline Vegetative stage & 100 \\
\hline Reproductive stage & 100 \\
\hline Maturity stage & 50 \\
\hline
\end{tabular}


Table.1 Geographical locations of 16 districts of Chhattisgarh state

\begin{tabular}{|c|c|c|c|}
\hline S. No. & Station & Latitude & Longitude \\
\hline 1 & Bastar & $19^{\circ} 05^{\prime} \mathrm{N}$ & $82^{\circ} 02^{\prime} \mathrm{E}$ \\
\hline 2 & Bilaspur & $22^{\circ} 05^{\prime} \mathrm{N}$ & $82^{\circ} 08^{\prime} \mathrm{E}$ \\
\hline 3 & Dantewada & $18^{\circ} 53^{\prime} \mathrm{N}$ & $81^{\circ} 21^{\prime} \mathrm{E}$ \\
\hline 4 & Dhamtari & $20^{\circ} 42^{\prime} \mathrm{N}$ & $81^{\circ} 34^{\prime} \mathrm{E}$ \\
\hline 5 & Durg & $21013^{\prime} \mathrm{N}$ & $81017 ' \mathrm{E}$ \\
\hline 6 & Janjgir & $22^{\circ} 01^{\prime} \mathrm{N}$ & $82^{\circ} 35^{\prime} \mathrm{E}$ \\
\hline 7 & Korba & $22^{\circ} 00^{\prime} \mathrm{N}$ & $82^{\circ} 42^{\prime} \mathrm{E}$ \\
\hline 8 & Koriya & $23^{\circ} 15^{\prime} \mathrm{N}$ & $82^{\circ} 34^{\prime} \mathrm{E}$ \\
\hline 9 & Kawardha & $22^{\circ} 01^{\prime} \mathrm{N}$ & $81^{\circ} 15^{\prime} \mathrm{E}$ \\
\hline 10 & Mahasamund & $21^{\circ} 06^{\prime} \mathrm{N}$ & $82^{\circ} 06^{\prime} \mathrm{E}$ \\
\hline 11 & Raigarh & $21^{\circ} 55^{\prime} \mathrm{N}$ & $83^{\circ} 24^{\prime} \mathrm{E}$ \\
\hline 12 & Raipur & $21^{\circ} 14^{\prime} \mathrm{N}$ & $81^{\circ} 39^{\prime} \mathrm{E}$ \\
\hline 13 & Rajnandgaon & $21^{\circ} 05^{\prime} \mathrm{N}$ & $81^{\circ} 02^{\prime} \mathrm{E}$ \\
\hline 14 & Surguja & $23^{\circ} 07^{\prime} \mathrm{N}$ & $83^{\circ} 12^{\prime} \mathrm{E}$ \\
\hline 15 & Bijapur & $18^{\circ} 50^{\prime} \mathrm{N}$ & $80^{\circ} 50^{\prime} \mathbf{E}$ \\
\hline 16 & Narayanpur & $22^{\circ} 29^{\prime} \mathrm{N}$ & $88^{\circ} 34^{\prime} \mathrm{E}$ \\
\hline
\end{tabular}

Table.2 Effect of drought at different stages on rice crop productivity (\% loss) in 4 districts of Chhattisgarh state

\begin{tabular}{|c|c|c|c|}
\hline \multirow{2}{*}{ Districts } & \multicolumn{3}{|c|}{ Drought at (\%) } \\
\hline Raipur & Seedling stage & Reproductive stage & Drought at all stages \\
\hline Bilaspur & 10.3 & 41.1 & 57.4 \\
\hline Jagdalpur & 12.2 & 27.2 & 53.7 \\
\hline Ambikapur & 6.3 & 20.2 & 41.2 \\
\hline
\end{tabular}

Table.3 Rainfall data base for different districts of Chhattisgarh state

\begin{tabular}{|c|l|c|}
\hline S. No. & \multicolumn{1}{|c|}{ Station } & Data base \\
\hline 1 & Bastar & $1910-2010$ \\
\hline 2 & Bilaspur & $1901-2010$ \\
\hline 3 & Dantewada & $1903-2010$ \\
\hline 4 & Dhamtari & $1901-2010$ \\
\hline 5 & Durg & $1901-2010$ \\
\hline 6 & Janjgir & $1901-2010$ \\
\hline 7 & Korba & $1901-2010$ \\
\hline 8 & Koriya & $1913-2010$ \\
\hline 9 & Kawardha & $1902-2010$ \\
\hline 10 & Mahasamund & $1906-2010$ \\
\hline 11 & Raigarh & $1901-2010$ \\
\hline 12 & Raipur & $1901-2010$ \\
\hline 13 & Rajnandgaon & $1902-2010$ \\
\hline 14 & Surguja & $1901-2010$ \\
\hline 15 & Bijapur & $1903-2010$ \\
\hline 16 & Narayanpur & $1903-2010$ \\
\hline
\end{tabular}


Table.4 Drought pattern during pre and post global warming periods in different districts of Chhattisgarh state

\begin{tabular}{|c|c|c|c|c|c|c|c|c|}
\hline \multirow[t]{2}{*}{ Districts } & \multicolumn{4}{|c|}{ Pre global warming (1931-1970) } & \multicolumn{4}{|c|}{ Post global warming (1971-2010) } \\
\hline & Large & Severe & Disastrous & Total & Large & Severe & Disastrous & Total \\
\hline Bastar & 4 & 0 & 0 & 4 & 5 & 1 & 0 & 6 \\
\hline Bilaspur & 4 & 0 & 0 & 4 & 8 & 1 & 0 & 9 \\
\hline Dantewada & 2 & 1 & 0 & 3 & 7 & 4 & 0 & 11 \\
\hline Dhamtari & 5 & 0 & 0 & 5 & 14 & 7 & 0 & 21 \\
\hline Durg & 5 & 1 & 0 & 6 & 10 & 5 & 1 & 16 \\
\hline Janjgir & 5 & 0 & 0 & 5 & 10 & 0 & 0 & 10 \\
\hline Korba & 3 & 3 & 1 & 7 & 9 & 2 & 0 & 11 \\
\hline Koriya & 5 & 1 & 0 & 6 & 10 & 2 & 1 & 13 \\
\hline Kawardha & 3 & 0 & 0 & 3 & 11 & 2 & 0 & 13 \\
\hline Mahasamund & 3 & 1 & 0 & 4 & 8 & 10 & 6 & 24 \\
\hline Raigarh & 1 & 0 & 0 & 1 & 13 & 8 & 1 & 22 \\
\hline Raipur & 5 & 0 & 0 & 5 & 11 & 2 & 0 & 13 \\
\hline Rajnandgaon & 6 & 2 & 0 & 8 & 13 & 2 & 1 & 16 \\
\hline Surguja & 5 & 1 & 0 & 6 & 11 & 3 & 1 & 15 \\
\hline Bijapur & 4 & 1 & 0 & 5 & 8 & 0 & 0 & 8 \\
\hline Narayanpur & 5 & 1 & 0 & 6 & 6 & 1 & 0 & 7 \\
\hline
\end{tabular}


Fig.1 Total drought pattern during pre (1931-1970) and post (1971-2010) global warming period

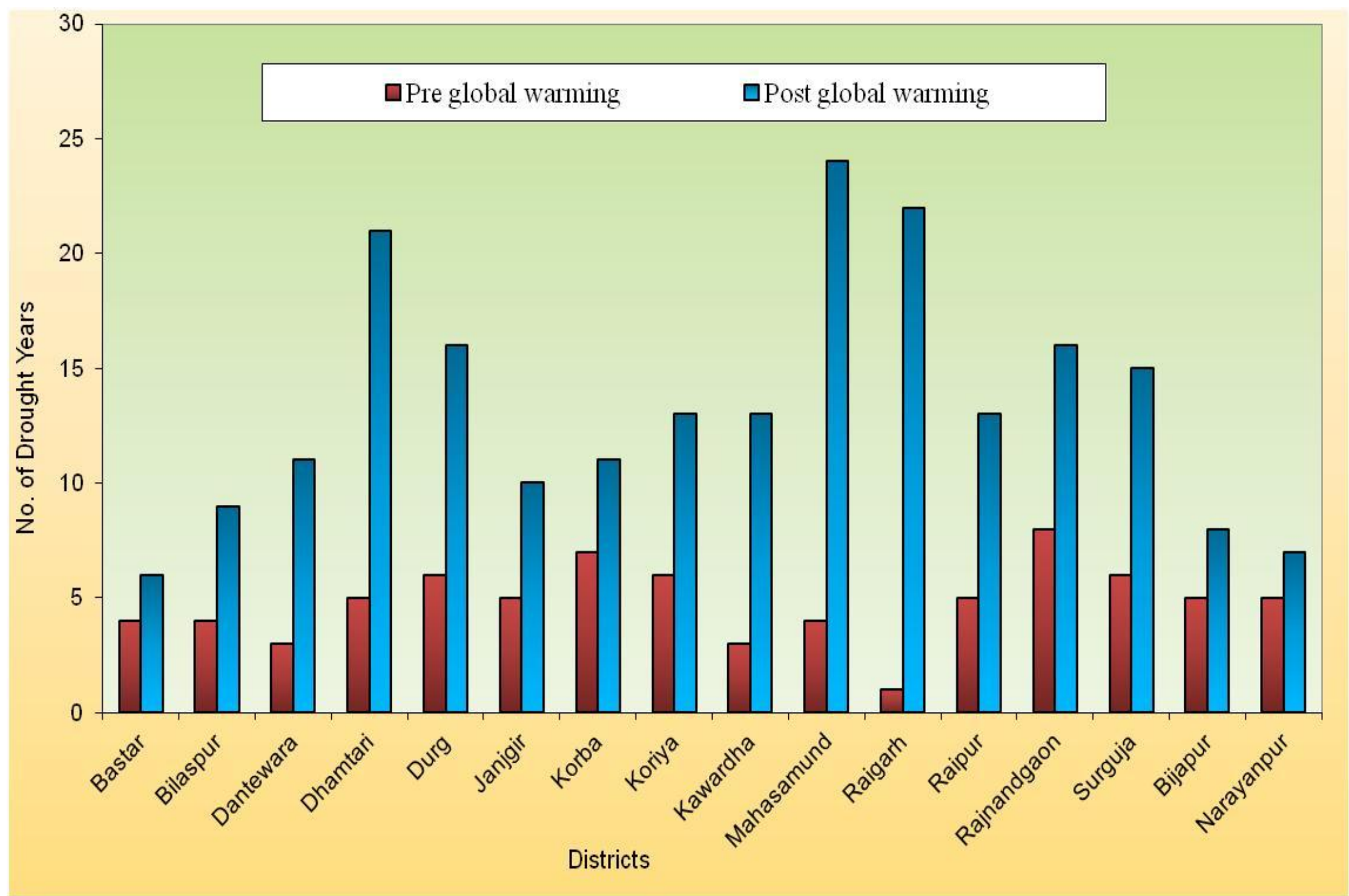


In Bilaspur district it varied from 24-27 SMW and in Jagdalpur district it varied from 23-26 SMW. Based on the sowing rain period the seedling, vegetative, reproductive and maturity stages of rice crop were considered as 4, 6, 6 and 3 weeks respectively from the sowing rain in week. Similar result finding Sastri (2006).

\section{Impact of drought /water stress at different growth stages of rice crop}

For assessing the impact of drought at different growth stage the Ima value needed at different growth stages, as mentioned earlier were graphically plotted. The weekly Ima values for 4 different districts for 10 year period (2001-2010) were super imposed on the pre plotted average Ima values. In each district the year with no drought, drought during seedling and reproductive stages and also years with drought in all stages were identified and corresponding productivity of rice was also depicted. The results are shown in Figure 1. The findings of the results for each district are discussed below.

\section{Raipur}

At Raipur under no drought condition, the rice productivity is $1836 \mathrm{~kg} / \mathrm{ha}$ while it is $1646 \mathrm{~kg} / \mathrm{ha}$ when there was seedling stage drought. Thus, there is reduction of $190 \mathrm{~kg} / \mathrm{ha}$ yield loss due to seedling stage drought which is 10.3 percent. Whereas during reproductive stage drought the productivity of rice was $1080 \mathrm{~kg} / \mathrm{ha}$.

Thus, due to reproductive stage drought, there is a yield loss of $756 \mathrm{~kg} / \mathrm{ha}$ which is 41.1 percent. When drought at all stages was examined, it was found that the productivity of rice was $781 \mathrm{~kg} / \mathrm{ha}$. Thus, there is a yield loss of $1055 \mathrm{~kg} / \mathrm{ha}$ due to drought at all stages which is 57.4 percent. The results are depicted in Figure 1.

\section{Bilaspur}

In case of Bilaspur the rice productivity under no drought condition is $1687 \mathrm{~kg} / \mathrm{ha}$. But the productivity in seedling stage drought is less than the same at reproductive stage (1228 $\mathrm{kg} / \mathrm{ha}$ ). This might be due to other reasons like pest infection. However, the yield loss due to reproductive stage drought is 1228 $\mathrm{kg} / \mathrm{ha}$ which is 27.2 percent. In case of drought at all stages, the productivity of rice decrease to $783 \mathrm{~kg} / \mathrm{ha}$ which is $904 \mathrm{~kg} / \mathrm{ha}$ and percentage wise it is 53.7 percent. The results are depicted in Figure 1.

\section{Jagdalpur}

At Jagdalpur the rice productivity under no drought condition is $1636 \mathrm{~kg} / \mathrm{ha}$. At seedling stage drought the productivity reduced to $1532 \mathrm{~kg} / \mathrm{ha}$. Thus, the yield loss due to seedling stage drought is $104 \mathrm{~kg} / \mathrm{ha}$ which is 6.3 percent. In case of reproductive stage drought the rice productivity had reduced to $1035 \mathrm{~kg} / \mathrm{ha}$. Thus, the yield loss due to reproductive stage drought is $331 \mathrm{~kg} / \mathrm{ha}$ which is 20.2 percent. The results are depicted in Figure 1.

In case when drought occurred during seedling and reproductive stages, the yield was $962 \mathrm{~kg} / \mathrm{ha}$. Thus, the yield loss due to seedling and vegetative stage drought is 674 $\mathrm{kg} / \mathrm{ha}$ which is 41.2 percent.

\section{Ambikapur}

In case of Ambikapur the rice productivity under no drought condition is $1555 \mathrm{~kg} / \mathrm{ha}$. At seedling stage drought productivity reduced to $1201 \mathrm{~kg} / \mathrm{ha}$. Thus, the yield loss due to seedling stage drought 22.7 percent. In case of reproductive stage drought the productivity of rice was $1135 \mathrm{~kg} / \mathrm{ha}$. Thus, the reproductive stage drought, there is a yield loss of 420 $\mathrm{kg} / \mathrm{ha}$ which is 27.0 percent. When drought at 
all stages was examined it was found that the productivity of rice was $1025 \mathrm{~kg} / \mathrm{ha}$. Thus, there is a yield loss of $530 \mathrm{~kg} / \mathrm{ha}$ due to drought at all stages which is 34.08 percent. The results are depicted in Figure 1. In a nut shell it can be seen from the Table 4 that the yield loss due to seedling drought varied from 6.3 to 22.7 percent. Highest loss was recorded at Ambikapur, perhaps due to reasons that the soils are light there. The yield loss due to reproductive stage drought varied from 20.2 to 41.7 percent while due to all stages drought the yield loss varied from 34.1 to 57.4 percent. Thus, water stress at any stage drastically reduces the productivity of rice under rainfed conditions.

In Chhattisgarh state in eastern India more than 80 per cent of the population is dependent on agriculture for their livelihood. Chhattisgarh state stretches between $80^{\circ} 15^{\prime}$ to $84^{\circ} 24^{\prime}$ E longitude \& $17^{\circ} 46^{\prime}$ to $24^{\circ} 5^{\prime} \mathrm{N}$ latitude. It covers total area of about 13.5 million hectare. At present the state has 27 districts. But the historical meteorological data is available for only 16 districts. Hence, the analysis of drought climatology of 16 districts of Chhattisgarh for the period of 1901 to 2010 was carried. It is found that the total numbers of drought years increased significantly in all the districts during post global warming period. In Mahasamund district during the pre-global warming period (1931-1970) the drought years were 4 years while in the post global warming period (1971-2010) there were 24 years. Similarly in Raigarh district during the pre-global warming period there is only 1 drought year in 40 years while in post global warming period there were 22 drought years. It was found that Mahasamund Dhamtari and Raigarh districts suffered from frequent droughts during the post global warming period. Bastar district had least number of drought years even during the post global warming period. The other districts which suffered from drought in the post global warming period are Rajnandgaon, Durg and Surguja districts followed by Raipur, Koriya and Kawardha districts. The crop sowing period was worked out with the concept of sowing rains. The sowing rains for each district were considered as "one or two consecutive weeks where there is rainfall of more than $50 \mathrm{~mm}$ ". It was found that in Raipur district the sowing rain period during the period of 10 years varied from 24 to 27 SMW while at Ambikapur it varied from 2429 SMW. In Bilaspur district it varied from 24-27 SMW. The seedling, vegetative, reproductive and maturity stages of rice crop were considered as 4, 6, 6 and 3 weeks respectively and based on this the crop duration was identified right from the sowing rain week. On the basis of super imposition of individual year Ima on the average requirement of Ima at different stages, the year with no drought, seedling stage drought, at reproductive stage drought and drought at all stages were identified. In Raipur district it was found that the rice productivity is 1836 $\mathrm{kg} / \mathrm{ha}$ under no drought condition while it is $1646 \mathrm{~kg} / \mathrm{ha}$ when there was seedling stage drought and the yield loss was 10.3 percent. In reproductive stage the yield loss was 41.1 percent and drought at all stages was 57.4 percent. In case of Bilaspur it was found that the productivity is $1687 \mathrm{~kg} / \mathrm{ha}$ under no drought condition while it is $1024 \mathrm{~kg} / \mathrm{ha}$ when there was seedling stage drought and the yield loss was 12.2 percent, while in reproductive stage it was 27.2 percent and in drought at all stages 53.7 percent. In case of Jagdalpur district it was found that the productivity is $1636 \mathrm{~kg} / \mathrm{ha}$ under no drought condition while it is $1532 \mathrm{~kg} / \mathrm{ha}$ when there was seedling stage drought and the yield loss was 6.3 percent. In reproductive stage drought the yield loss was 20.2 percent and in drought at all stages drought 41.2 percent. In case of Ambikapur it was found that the productivity is $1555 \mathrm{~kg} / \mathrm{ha}$ when there was seedling stage drought and 
the yield loss was 22.7 percent, in reproductive stage drought the yield loss was 27.0 percent and in drought at all stages it was 34.1 percent.

\section{References}

Baghel, S. S. and Sastri, A. S. R. A. S., 1992, "Regional climate change and its influence on agriculture - A case study for Chhattisgarh region of Madhya Pradesh", First Agricultural Science Congress, 213-222.

Das, H. P., Geonkar, S. B., E. I. and Pandey, V. K., 2002, "Evaluation of agricultural drought for dryland crop", Mausam. 53 (3): 375-380.

Jadhav, J. D., Mckashi, D. D., Shcwale, M. R. and Patil, J. D., 1999, "Rainfall probability analysis for crop planning in scarcity zone of Maharashtra", Journal of Agrometeorology, 1, 1, 59-64.

Paul, J. C., Sahu, A. P. and Sharma, S. D., 2001, "Water balance study of Bhubaneswar A decade change", Journal of Soil and Water Conservation. 45, 3-4, 167-172.

Rawat, L. and Rawat, V. R. S., 1995, "Changes in hydrology and water balance of new forest Dehradun Indian", Soil Conservation, 23, 2, 8992.

Sarkar, J. 2000, "Agricultural droughts of 1987 monsoon season in India", Journal of Agrometeorology. 2, 1, 55-60.

Sastri, A. S. R. A. S., 2006, "Agricultural drought: Concepts, assessment and management. Director of Research IGAU, Raipur (C.G.)" Central Research Institute for Dryland Agriculture, Hyderabad, India.

Sastri, A. S. R. A. S., Chaudhary, J. L., Shrivastava, A. K. and Naidu, D., 1997, "Water harvesting potential in Chhattisgarh plains - A hydroclimatic Analysis", Bhagirath", 44, 1, 15-21.

Sastri, A. S. R. A. S., Rao H. G., Naidu, D. and Yadav S., 2002, "Project report on drought analysis and its impact on rice productivity in Chhattisgarh", IGAU, Raipur, 7-8.

Srivastasva, A. K., Sastri, A. S. R. A. S. and Naidu, D., 2000, "A note on drought and rice productivity in Chhattisgarh state", Journal of Agrometeorology, 2, $1,75-81$.

Subramaniam, A. R. and Srimannarayana, T. 1991, "Climatic Studies of Madhya Pradesh", Trans. Inst. Indian Geographers, 13, 1, 73-81.

Subramaniam, S. K., 1994, "How far the rainfall deficiency in June-July is made up during second half of Lie south west monsoon period/ A sub divisional analysis", Vayumandal. 24, 3-4, 72-76.

Suresh, R., 1996, "Inter seasonal and inter annual rainfall variability of a meteorological sub division in peninsular India', Vayumandal. 26, 1-2, 27-31.

Thornthwaite, C. W. and Mather, J. R., 1955, "The water balance Laboratory of Climatology", No. 8, Centerton N. J.

\section{How to cite this article:}

Yogesh Mahesh, A.S.R.A.S. Sastri, S.K. Chandrawanshi, Pandurang Bobade, Hemant Kumar Bhuarya, Deepak K. Kaushik and Pritpal Singh. 2018. To Examine the Drought Pattern during Pre and Post Global Warming Behind and it Impacts on Rice Productivity for Different Districts of Chhattisgarh, India. Int.J.Curr.Microbiol.App.Sci. 7(11): 261-272. doi: https://doi.org/10.20546/ijcmas.2018.711.032 